\title{
ADDISONIAN CRISIS AS A MANIFESTATION OF A PARTIALLY EMPTY SELLA IN A 68-YEAR-OLD WOMAN
}

Mouslech Z.1 , Somali M.', Sakali A.K. ${ }^{2}$, Koulara P. ${ }^{1}$, Mourouglakis A. ${ }^{1}$, Tsoutsas G. ${ }^{1}$, Savopoulos Ch. ${ }^{1}$, Mastorakos G. ${ }^{2}$, Hatzitolios A.I. ${ }^{1}$

11 $1^{\text {st }}$ Medical Propedeutic Dept of Internal Medicine, Aristotle University of Thessaloniki, AHEPA University Hospital, St. Kyriakidis 1, P.O. 54636, Thessaloniki, Greece

${ }^{2}$ Department of Endocrinology, Metabolism and Diabetes, Aretaieio Hospital, School of Medicine, University of Athens, 76 Vas Sofias Avenue, P.O. 11528, Athens, Greece

\section{OBJECTIVES}

Empty sella syndrome (EES) is a condition often discovered incidentally, where the sella turcica, the structure containing the pituitary gland, appears to be empty.

Patients either remain asymptomatic or, rarely, manifest signs of declined pituitary function. Patients experiencing hypopituitarism are offered hormonal replacement.

Autopsy studies estimated a 5\% EES prevalence among healthy individuals.

\begin{tabular}{|c|c|c|c|}
\hline \multicolumn{2}{|c|}{ Patient's laboratory results } & \multirow{2}{*}{$\begin{array}{l}\text { Normal values } \\
>10.0 \mathrm{mlU} / \mathrm{ml}\end{array}$} & $\begin{array}{l}\text { Short Synachten test } \\
\text { conventional-dose } \\
250 \mu \mathrm{g} \text { Cosyntropin }\end{array}$ \\
\hline LH & $0.20 \mathrm{mlU} / \mathrm{ml}$ & & Cortisol $0 \mathrm{~min}$ \\
\hline FSH & $1.30 \mathrm{mlU} / \mathrm{ml}$ & $>30.0 \mathrm{mlU} / \mathrm{ml}$ & Cortisol $30 \mathrm{~min}$ \\
\hline PRL & $104.0 \mu \mathrm{Ul} / \mathrm{ml}$ & $102.0-496.0 \mu \mathrm{Ul} / \mathrm{ml}$ & Cortisol $60 \mathrm{~min}$ \\
\hline TSH & $0.18 \mu \mathrm{lU} / \mathrm{ml}$ & $0.27-4.2 \mu \mathrm{lU} / \mathrm{ml}$ & \\
\hline FT3 & $3.40 \mathrm{pmol} / \mathrm{l}$ & $3.1-6.8 \mathrm{pmol} / \mathrm{l}$ & \\
\hline FT4 & $6.01 \mathrm{pmol} / \mathrm{tt}$ & $12.0-22.0 \mathrm{pmol} / \mathrm{tt}$ & \\
\hline ACTH $8.00 \mathrm{am}$ & $17.30 \mathrm{pg} / \mathrm{ml}$ & $10.0-60.0 \mathrm{pg} / \mathrm{ml}$ & \\
\hline CORT $8.00 \mathrm{am}$ & $51.0 \mathrm{nmol} / \mathrm{l}$ & $171.0-536.0 \mathrm{nmol} / \mathrm{l}$ & $\begin{array}{l}\text { MRI of the pituitary gland } \\
\text { demonstrating a partially } \\
\text { empty sella turcica }\end{array}$ \\
\hline
\end{tabular}

\section{METHODS}

Case report: A 68-year-old post-menopausal woman, overweight (BMI=29), mother of 3 children, presented with a 3-day history of fever $\left(T=38,5^{\circ} \mathrm{C}\right)$, excessive vomiting and nausea and a history of 15 days of anorexia, weakness and fatigue.

Five years ago, during the course of a hospitalization for the investigation of leukopenia, she was diagnosed with myelodysplastic syndrome and received treatment with pegfilgrastim and epoetin beta.

\section{RESULTS}

Physical examination yielded no pathological findings, whereas laboratory results revealed leukopenia $(\mathrm{WBC}=2.900)$, hypokalemia( $\left.\mathrm{K}^{+} 3.2 \mathrm{mmol} / \mathrm{lt}\right)$, low $\mathrm{TSH}$ levels $=0.18 \mu \mathrm{lU} / \mathrm{ml}$ (n.v.0.27-4.2 $\mu \mathrm{lU} / \mathrm{ml}$ ), low FT4=6.01 pmol/lt, (n.v.12.0-22.0 $\mathrm{pmol} / \mathrm{lt}$ ), decreased gonadotropin levels $(\mathrm{FSH}=1.3 \mathrm{mlU} / \mathrm{ml}$, n.v. in menopause $>30.0 \mathrm{mlU} / \mathrm{ml}$ and $\mathrm{LH}=0.2 \mathrm{mlU} / \mathrm{ml}$, n.v. in menopause $>10.0 \mathrm{mlU} / \mathrm{ml}$ ), hypocortisolemia (cortisol=51.0 $\mathrm{nmol} / \mathrm{l}$, n.v.171.0-536.0 nmol/l) and low normal $\mathrm{ACTH}=17.3$ $\mathrm{pg} / \mathrm{ml}$ (n.v. $10.0-60.0 \mathrm{pg} / \mathrm{ml}$ ).

The patient underwent adrenal function investigation with the short Synacthen test, where she responded positively (cortisol $0 \mathrm{~min}=110.0 \mathrm{nmol} / \mathrm{l}, 30 \mathrm{~min}=283.0 \mathrm{nmol} / /, 60 \mathrm{~min}=410.0 \mathrm{nmol} / \mathrm{l}$ )

MRI of the pituitary gland demonstrated a partially empty sella turcica, with herniation of the suprasellar cistern.

The patient was diagnosed with panhypopituitarism and was initially treated with i.v. administration of methylprednisolone.

After discharge, outpatient treatment included levothyroxine and prednisone.

\section{CONCLUSIONS}

Empty sella may be primary or secondary to surgery, irradiation or infarction of the pituitary gland. Idiopathic ESS usually generates from congenital defects of the sellar diaphragm where arachnoid membrane herniates through the deficient diaphragm, compressing the pituitary gland. In up to $50 \%$ of the cases, primary ESS is associated with benign intracranial hypertension.

MRI usually demonstrates the compression of the pituitary tissue against the floor of the sella and the subsequent deviation of the pituitary stalk. Hypopituitarism manifests when $>90 \%$ of the pituitary tissue is compressed or atrophied. 